\title{
The Pulses of the Mekong River Basin: Rivers and the Livelihoods of Farmers and Fishers
}

\author{
Lois Wright Morton'1, Kenneth R. Olson ${ }^{2}$ \\ ${ }^{1}$ Department of Sociology, College of Agriculture and Life Sciences, Iowa State University, Ames, IA, USA \\ ${ }^{2}$ Department Natural Resources and Environmental Sciences, College of Agricultural, Consumer, and Environmental Sciences, \\ University of Illinois, Urbana, IL, USA \\ Email:1wmorton@iastate.edu,krolson@illinois.edu
}

How to cite this paper: Morton, L.W. and Olson, K.R. (2018) The Pulses of the Mekong River Basin: Rivers and the Livelihoods of Farmers and Fishers. Journal of Environmental Protection, 9, 431-459. https://doi.org/10.4236/jep.2018.94027

Received: March 28, 2018

Accepted: April 27, 2018

Published: April 30, 2018

Copyright $\odot 2018$ by authors and Scientific Research Publishing Inc. This work is licensed under the Creative Commons Attribution International License (CC BY 4.0).

http://creativecommons.org/licenses/by/4.0/

\section{(c) (i) Open Access}

\begin{abstract}
The transboundary Mekong River is shared by six SE Asia countries (China, Myanmar, Thailand, Lao PDR, Cambodia, and Vietnam). In this paper the livelihoods of farmers and fishers of Lao PDR, Cambodia and Vietnam are examined to assess impacts of Mekong River development and modernization projects on the rural peoples of the Mekong River and Delta. A high proportion of the 190 million rural people of the Mekong basin are dependent on the diverse and abundant resources of the Mekong River and its tributaries for food security and basic necessities, livelihoods, and cultural identities. Although rice farming and fisheries occupations are primary income sources, many livelihoods involve a diversity of on-farm and off-farm activities. Agricultural specialization and intensification and hydropower dam construction on the Mekong main stem and tributaries are altering traditional rural patterns of household food security, income, and cultural ways of living at an increasingly rapid pace. Rural transformation projects must better assess how these modernization efforts change the ecology of the Mekong River and in turn affect the capacity of rural people to adapt in ways that ensure food security and improve household livelihoods. It will be critical that development efforts recognize, value, and invest in rural people's roles in producing a stable, affordable food system and managing the integrity of river ecosystems upon which future prosperity depends. Interventions are needed to prevent degradation of the Mekong Basin soil and water resources from large-scale agricultural intensification, water diversion and overbuilding of hydropower dams which are threats to small-scale land holdings and farmers and fishers capacities to provide daily food for their own consumption and to feed SE Asia's growing urban populations.
\end{abstract}

\section{Keywords}

Mekong River Basin, Farmers, Fishers, Livelihoods, Hydropower, Rice, 
Fish, Agricultural Intensification

\section{Introduction}

Small-scale farmers and fishers of the Mekong River basin produce over $80 \%$ of the fish, rice, and vegetables of southeast (SE) Asia [1]. Most of these rural people live near or along natural rivers, streams or seasonally flooded areas in villages in close proximity to permanent waters [2]. The farmers and fishers of Lao PDR, Cambodia, and the Vietnam Mekong Delta are dependent on the diverse and abundant resources of the Mekong River and its tributaries for food security and basic necessities, livelihoods, and cultural identities. The majority of their household incomes are derived from farming, primarily rice (Oryza sativa) production. Although occupational censuses show farming as a dominant driver of regional economies, livelihood strategies are diverse with fishing and aquaculture as well as livestock providing critical household food resources and supplements to incomes [2] [3] [4] [5]. Sixty to $95 \%$ of rural households in these countries are involved in capture fisheries or aquaculture [2] concurrently with farming. For example, the Cambodian floating villages and rural households along the Tonle Sap River and Lake (Figure 1) obtain 16\% of their total 2121 calories per capita per day and most of their protein, micro nutrients, and fatty acids from their fish catch [5].

The productive Mekong ecological system and tropical climate have supported the habitats of unique flora and fauna and a succession of rural livelihoods, human civilizations and empires [6]. As a transboundary river shared by six countries, it is of great ecological, economical, social and political interest and the source of numerous small and large-scale conflicts [7] [8]. It is also home to some of the poorest people in the world [1] [6] [9]. In recent years, there have been significant public-private investments in structural and rural transformation projects intended to develop and modernize the countries of the Mekong River Basin, grow national economies, increase incomes, and assure access to clean drinking water and electricity. While benefiting some countries and sectors, these changes have had intended and unintended consequences to the livelihoods of many rural people.

The rapid growth of hydropower dams (Figure 2), agricultural specialization and intensification, global markets, and urban industrialization have benefited cities and industrial zones far from the rural places that are the source of resources used to modernize. And much too frequently these projects leave rural people and their communities only marginally better off and often worse off [10]. Many of these modernization and development efforts threaten not only the Mekong natural resource base but also millions of small-scale farmers and fishers that are the underpinning of regional food systems and food security [1] [11]. Of particular concern is the ecological degradation of the Mekong region 


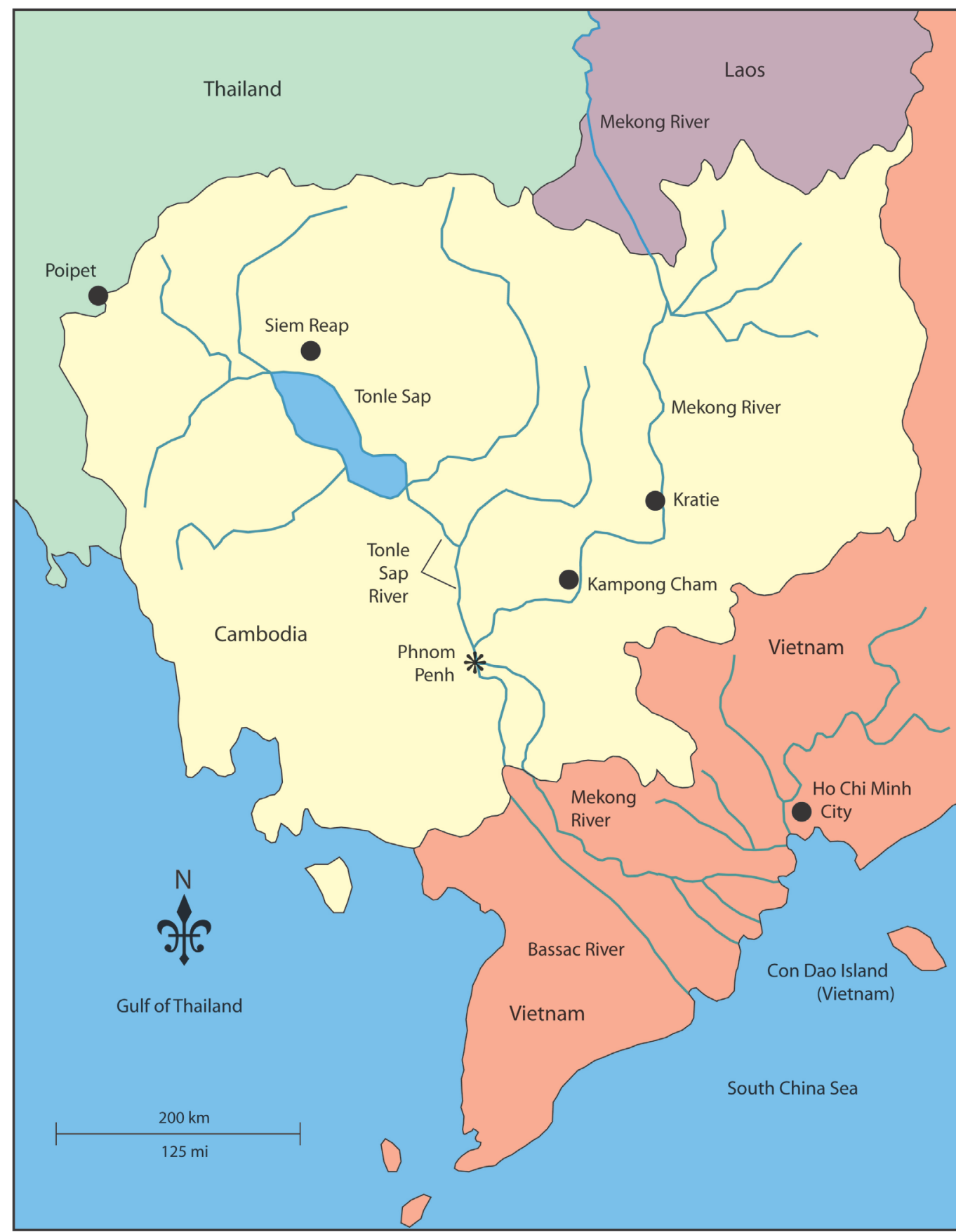

\section{Legend}

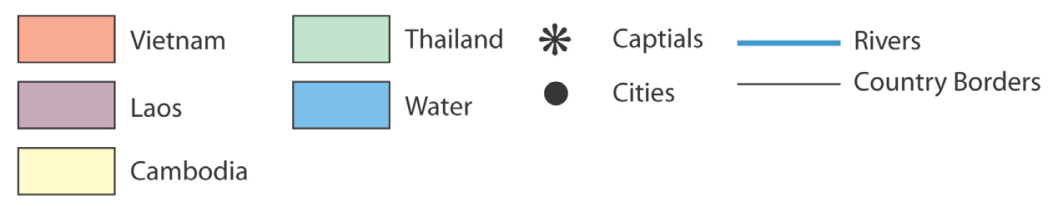

Figure 1. The alluvial sediments and nutrients in the great lake of Cambodia (Tonle Sap Lake) support an abundance of fish and other aquatic species used by rural people for household food and fisheries incomes. Reprinted with permission Figure 2 in Olson and Morton. 2018b. Tonle Sap Lake and river and confluence with the Mekong River in Cambodia. Journal of Soil and Water Conservation 73:3:60A-66A. Map by Mic Greenberg. 


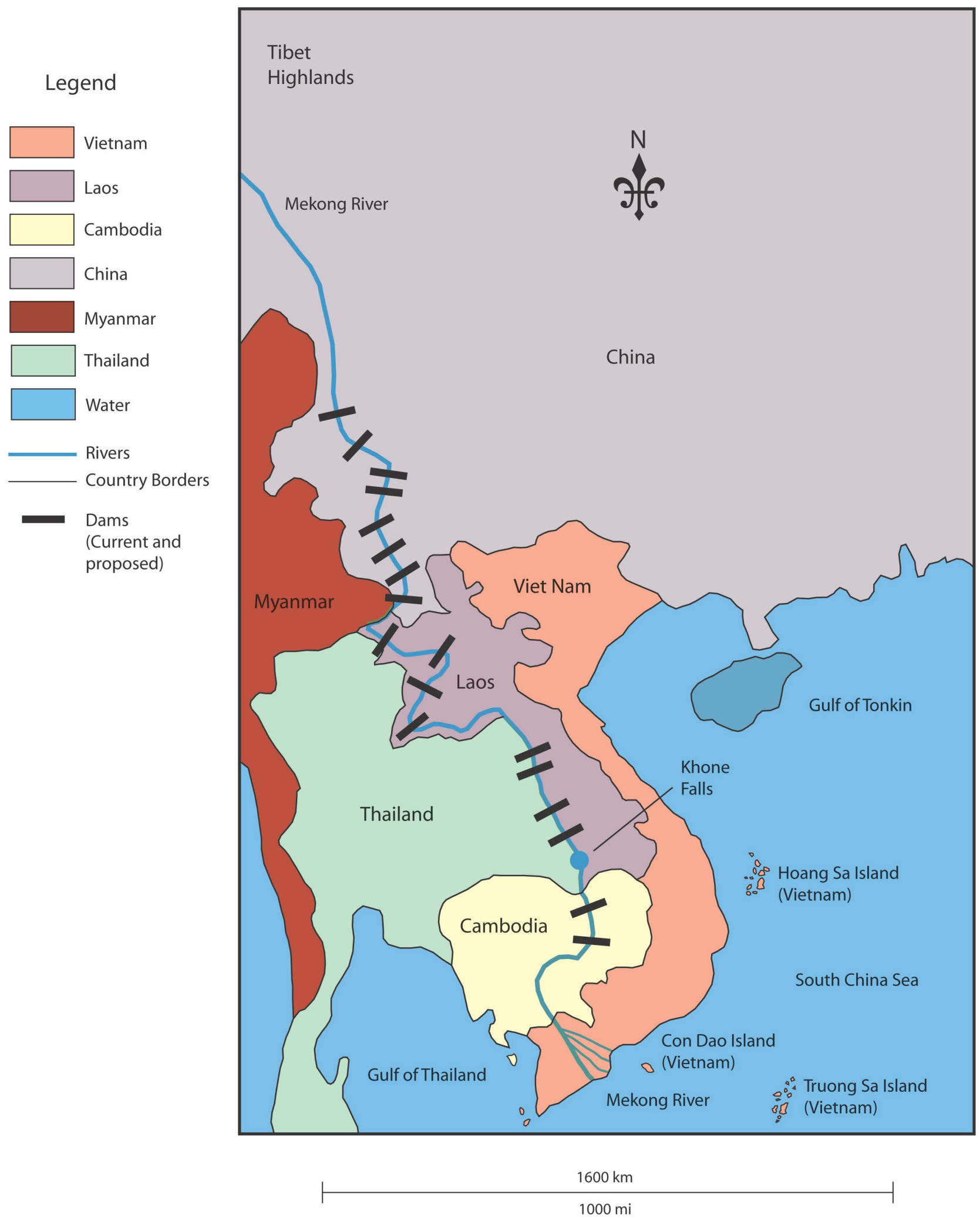

Figure 2. Proposed and constructed hydropower dams on the main stem of the Mekong River produce electricity and are important sources of export income for development and modernization projects. Reprinted with permission Figure 6 in Olson and Morton. 2018a. Water rights and fights: Lao dams on the Mekong River. Journal of Soil and Water Conservation 73:2:35A-41A. Map by Mic Greenberg. 
water and soil resources, pesticide and industrial pollution, salinity incursions from sea level rise, changes in river flows and sedimentation brought on by dam construction and water diversion, and increasing conflicts among interest groups and geographies along the river [5] [6].

The development discourse, in search of solutions to economic progress often undervalues the rural people resource that is needed to take SE Asia into the $21^{\text {st }}$ Century. Rural outmigration to urban places has not been a pathway to prosperity. Rather data show rural people who remain in rural areas in SE Asia are more likely to be food secure and more likely to escape poverty than those who move to cities [1]. Rural household occupational multiplicity offers flexibility and resilience under social and technological change, drought, flooding, social conflict, and economic ups-and-downturns [4] [12]. This diversity in livelihood strategies can strengthen capacities to be more food secure and accumulate sufficient resources to take advantage of opportunities. How can development projects build on rural cultural worldviews and their knowledge and experiences with river and floodplain systems of agriculture and fisheries? And how can household livelihood goals be achieved while encouraging innovation and adoption of appropriate technologies that support better management of the Mekong landscape [3]?

A starting point in answering these questions is to better understand the current roles Mekong farmers and fishers play in the food system; and their future potential in protecting and managing the soil and water resources of the main stem river, tributaries and floodplains. In this paper, we explore the connection Mekong farmers and fishers have with their water and soil resources; and how the geography and physical characteristics of the region affect livelihoods, income and food security, and shape cultural worldviews. We ask, what are the resources and policies rural people need to strengthen their livelihood strategies so they can thrive, provide food for themselves and urban populations, and ensure the environmental integrity of the Mekong basin for future generations?

First, concepts of livelihoods and income diversification are applied to the farmers and fishers of the Mekong. Then, the biophysical nature and diversity of the Mekong River Basin are presented in light of the resources they provide to rural people who live there. This is followed by a discussion of two modernization efforts intended to bring economic prosperity to individual countries and the region: agricultural specialization and intensification and hydropower infrastructure. Examples based in the geography of the Mekong River and its tributaries in Lao PDR, Cambodia and the Vietnam Mekong Delta are offered to illustrate the intimate and dependent individual and social relationships that are formed by occupations that are in daily contact with the riverine environment. Lastly, the impacts and potential solutions for mitigating the collision between modernization and rural livelihoods rooted in the natural environment and a culture that builds on past knowledge and experiences are discussed.

\subsection{Rural Livelihoods and Income Diversification}

Farmers and fishers of the Mekong River basin have a long legacy of diverse live- 
lihood strategies that are widespread and found across farm sizes and wealth groups [4] [13]. Livelihoods are defined as the economic and non-economic self-reliance strategies people use to survive and thrive [12]. In SE Asia these survival strategies are strongly influenced by the local natural resource base, knowledge and skills, and the social relationships and institutions that mediate access to assets and income streams [12] [14]. This is illustrated by Taylor [13] who describes the distinct relationship of the Khmers of the Vietnam Delta region as a people with a poetic and spiritual connection to the land and waters of their region. The Khmers are not alone in how they view their relationship to land and water and its value. One fisher of the Siphandone area, Lao PDR says "...we were born as fisherman," this is who we are and what we do. Another farmer elaborates that their river villages have "enough food to eat, people respect each other and have enough money to use for supporting their families" [15]. The intimacy rural people feel with the river as essential to life is expressed by a village leader, "We rural people don't mind to go to the river to drink [and] bathe;" collecting water is part of daily life [16].

Most of the rural people who live in the greater Mekong region are engaged in agriculture and depend on natural resources for food, income, and their livelihoods [5] Access to fresh water, fertile soils, water transport systems and roads connecting to markets are key underpinnings of rural livelihoods. Rice farmers typically own/manage 0.5 to 2 ha. Metrics of prosperity include hectares of land owned, number of livestock (e.g. cows, water buffalo)owned, house construction (stilts above the water vs on the ground), a speed boat to take products to market, and fresh safe drinking water especially in the dry season. And more recently, a number of rural households have a motorbike to transport products and people.

Rural livelihoods include a portfolio of agricultural activities-rice, vegetables, livestock, fruit and nuts, fisheries (fish, shrimp, eel and other water-based species), off-farm wages, as well as non-farm activities including urban-rural remittances [4] [17]. Occupational multiplicity within households and across households is both by necessity for survival and by choice to accumulate resources [12]. Necessity refers to involuntary diversification that may be the result of loss of access to land, fishing grounds, crop failure, war dislocation or abandonment of assets, or loss of physical capacity to engage in strenuous agricultural activities due to injuries or poor health. In contrast, Ellis [12] defines choice as voluntary, forward-looking diversification strategies such as adding new crops to their mix, taking advantage of market opportunities and seeking off-farm income to support farm inputs and capital investments. These strategies are not mutually exclusive and motivations and constraints are culturally, socially, and time-space-scale sensitive.

\subsection{Rice Farming Systems}

Rice-based farming systems are the foundation of SE Asia livelihoods [3]. More 
than one-third of rice harvested (Figure 3) world-wide is produced by SE Asia farmers [18] of which almost $45 \%$ is irrigated. Farmers living in the river deltas of Vietnam, Cambodia, and Lao PDR had more than 7.2 million ha of rainfed (3.398 million ha) and irrigated rice (3.881 million ha) under production in early 2000s [18]. Investments in new rice varieties, fertilizers and pesticides in conjunction with hydrologically managed drainage systems called dikes and polders (Figure 4) have expanded traditional rainfed wet season rice production to dry season irrigated systems.

The Vietnam Mekong and Red river deltas are intensively cultivated using these technologies enabling farmers to produce two to three rice crops a year of which almost 3.7 million ha are irrigated. As a result Vietnam farmers' rice yields are more than $134 \%$ greater than the yields of Cambodian rice farmers who typically plant only traditional wet season rice varieties [19]. Large variations in yields are associated with seed variety, soil fertility, drainage/irrigation, variability in climate, fertilizer, pesticides and extension crop technical support [18] [19]. In recent years there has been a big push by SE Asian governments to intensify rice production by increasing yields per hectare and number of hectares planted to rice. In 2015, Vietnam rice hectares were estimated at 7.7 million ha, Cambodia had grown to 3.1 million ha and Lao had almost 1million ha of rice under cultivation [19].

\subsection{Fishers and Fisheries}

Although most rural people in the lower Mekong River Basin are farmers, fisheries is a common secondary occupation (Figure 5) [2]. The term "fisheries" encompasses wild catch and aquaculture of fish and shrimp including a wide variety of other aquatic animals (e.g. crabs, mollusks, insects, reptiles, amphibians)

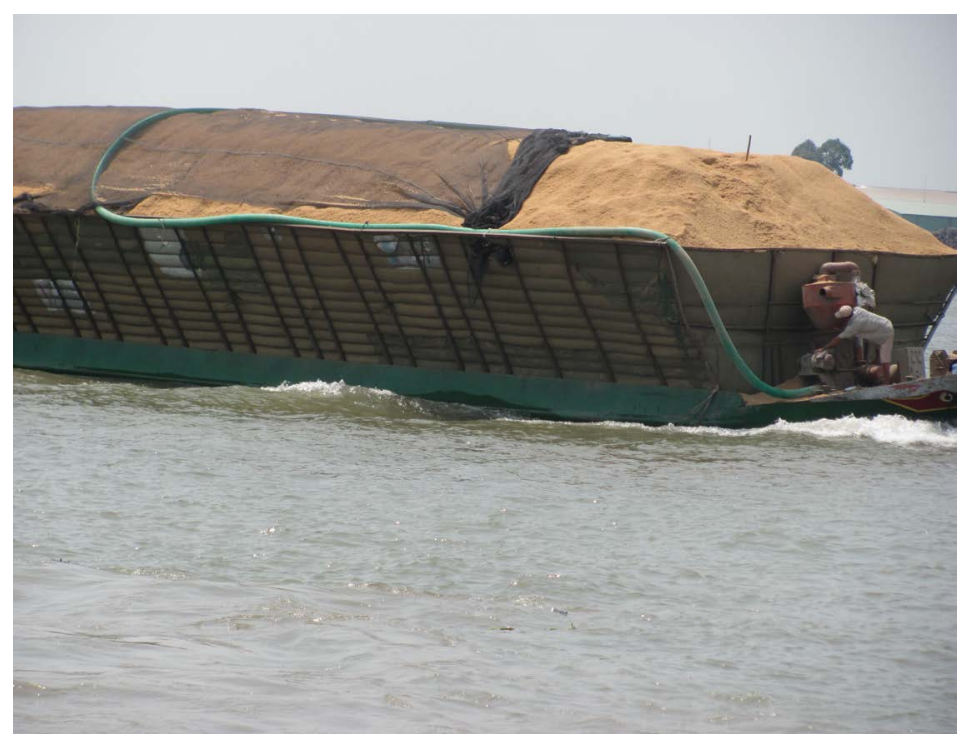

Figure 3. Rice is transported down the Mekong River to port in the Vietnam Delta for export. Vietnam farmers produced 5.89 tons per hectare of rice on 7.7 million hectares in 2015. 


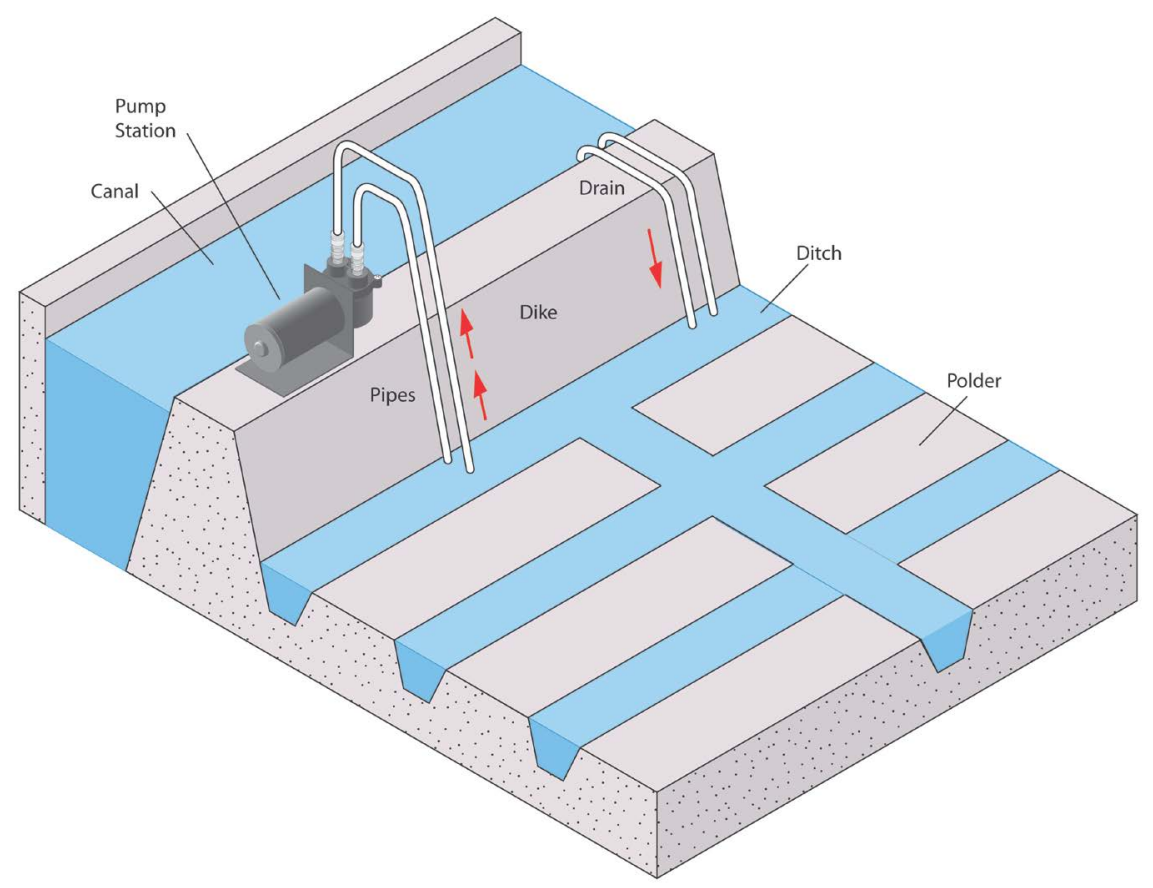

Figure 4. Dike and polder drainage and irrigation system. Reclaimed drained lowland (polder) is surrounded by dikes which prevent outside water from coming into the polder. A pumping station brings water into the agricultural field (polder) from the canal or river during dry season and pumps excess water back into the canal during the wet season. Drawing by Mic Greenberg.

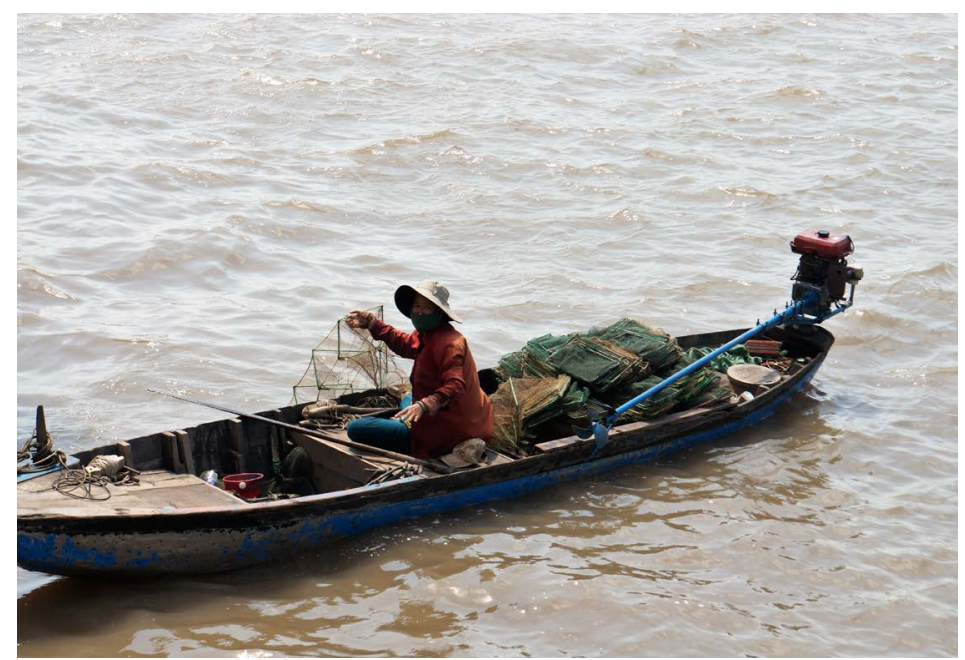

Figure 5. A fisher in the Mekong River drops a net off the side of her boat. The propeller and motor of her speed boat can also be used to pump irrigation water to vegetable and rice crops during the dry season.

[2]. Fisheries engage the entire value chain from catch and farmed to cleaning, drying, pickling and processing to marketing (Figure 6). Livelihood diversification strategies associated with fisheries industries are boat-building, making nets and fishing gear, selling ice and salt, and gathering wetland reeds, grasses and other plants. The sale of fish and fisheries products contributes to about $25 \%$ of 


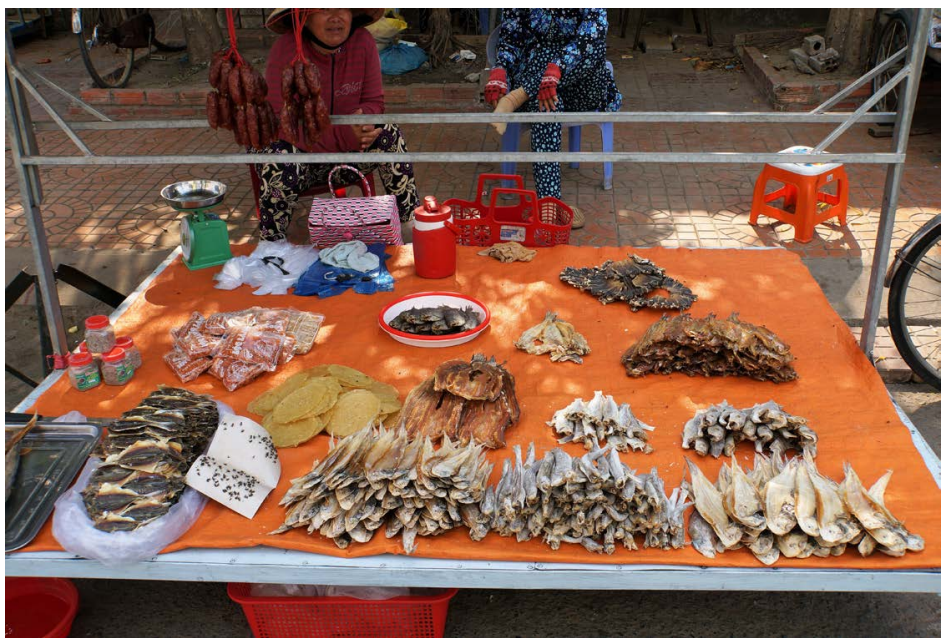

Figure 6. Fisheries catch and farm, clean, dry, pickle and process a wide variety of fish and other aquatic species including mollusks, insects, and amphibians.

SE Asian rural incomes in general and almost all the income for $40 \%$ of households in the Tonle Sap area (Figure 1) of Cambodia [5]. A growing number of fishers have replaced wild fish catches with aquaculture as urban and export markets have grown. Aquaculture is the cultivation of fish, shrimp, freshwater prawns and other water-based animals and plants under controlled conditions in lakes, rivers, wetlands, ponds, and offshore in the South China Sea. Aquaculture farming involves breeding, hatching and rearing freshwater or saltwater species in nets and ponds that confine them, protect against predators, and allow specific feeding regimes to accelerate growth.

\subsection{Livelihood Diversification}

Although rice and fish are major components of Mekong farmers and fishers food supply and income, they also grow a diverse range of tropical fruits, nuts and vegetables; livestock; and forestry products such as rubber on natural levees, coastal dunes, river banks, alluvial aprons and uplands (Figure 7) [8] [11] [13] [20]. Banana (Musa sp.), dragon fruit (Hylocereus undatus), cashew (Anacardiumoccidentale), and other tropical fruit and nut trees need freshwater and good drainage and are located on natural levees and uplands. Wild insect catch and farmed have found a niche market in the cash economy and as a household high value protein source.

High rainfall, humidity and the alternating wet and dry tropical climate of the Mekong Delta create ideal conditions for fast reproduction of many types of insects. Although insects can harm agricultural crops and carry diseases, the farmers of the region have innovatively turned this abundance into a profitable market for high quality protein (Figure 8). According to the Food and Agriculture Organization [21] insects are healthy and nutritious alternatives to fish and meat. Many insect varieties are rich in protein, fat, calcium, iron and zinc. For 


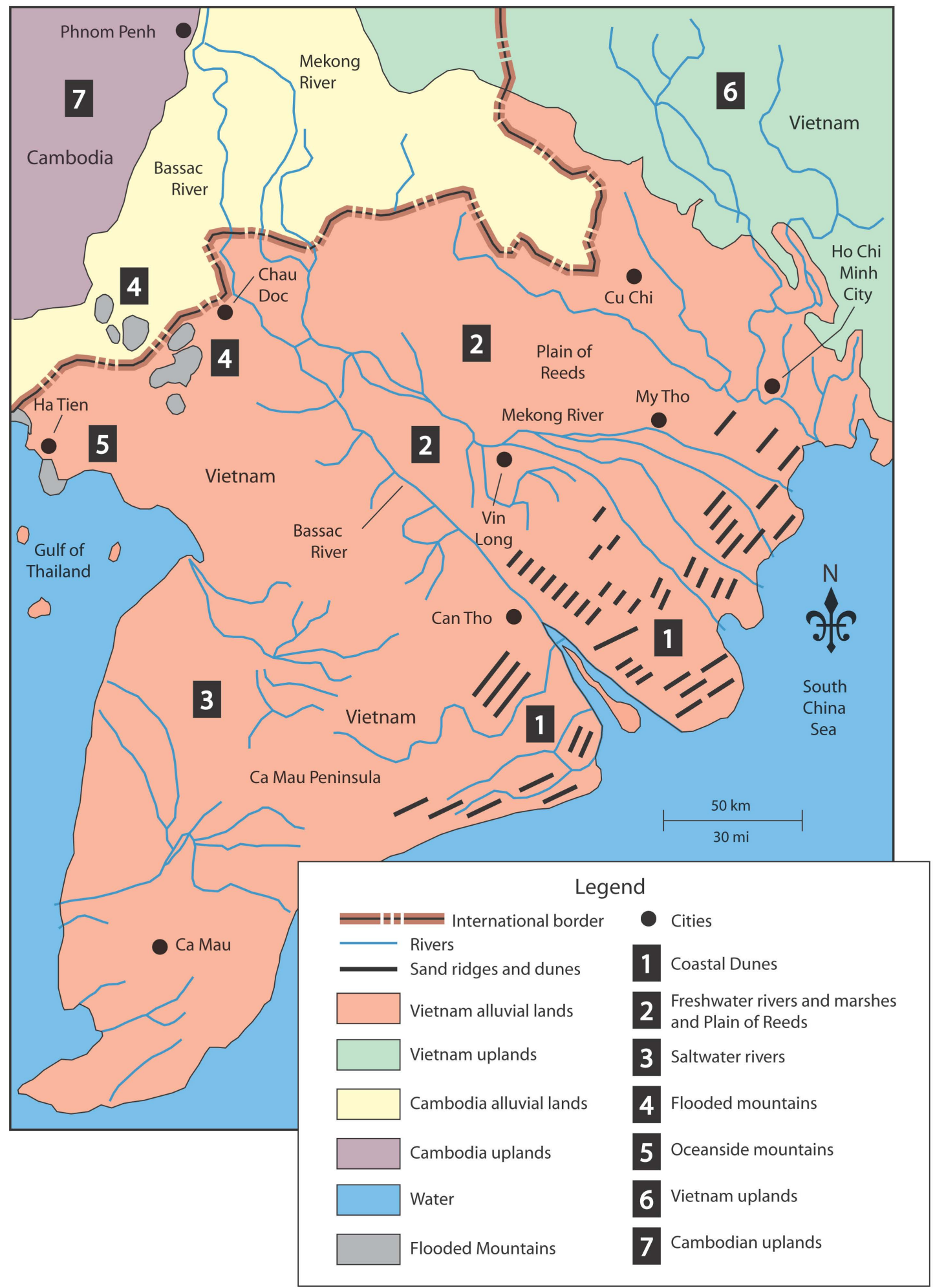

Figure 7. As the Mekong River flows south through the Mekong Delta it waters a diverse landscape bringing freshwater to the lowlands around the flooded mountains and saltwater river regions in the wet season and sediment loads that replenish the fertility of rice fields. Coastal dunes along the South China Seas are high points above sea-level salty, acidic soils and are used for catching and storing rainwater, village homes, and fruit trees and vegetables that need good drainage and freshwater. Farmers in the uplands of Vietnam, Cambodia and Lao PDR grow coffee, rubber, fruit and nut trees. Map by Mic Greenberg. 


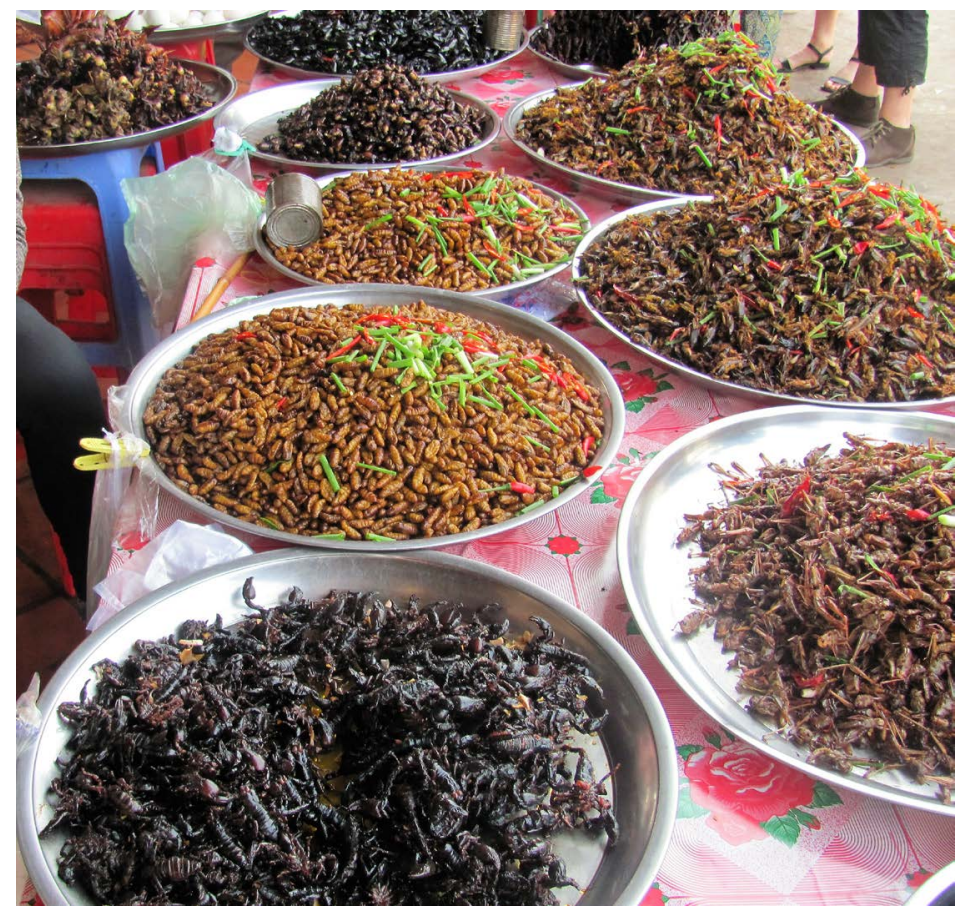

Figure 8. A local market in Cambodia sells a variety of insects. Selling insects is a profitable addition to household and farm incomes.

example, crickets are on average $60 \%$ protein (based on dry matter weight) which is roughly the same as animal meat [22] [23]. The high reproductive capacity of insects and short life cycle allow high biomass production in a very small space requiring very little capital to produce.

Many farmers and fishers are involved throughout the agricultural value chain-growing, processing, packaging and marketing their products. Rural highlanders and riverbank farmers who are close to city markets bring their food products and handicrafts such hand-woven silk and cotton fabrics and rugs to sell. The valleys of tributaries near small mountain villages and cities, such as Luang Prabang, Laos are tourist destinations that offer farmers and fishers ready market access to their products. Raised beds in the valleys grow a variety of vegetables and often employ five or more family members and friends. These plots must be irrigated daily during the dry season to ensure year around produce for urban markets and are often watered manually (Figure 9). A number of tributaries in Laos and Cambodia have small pocket dams (Figure 10) that are used for rice and vegetable irrigation, fisheries, and hydroelectricity [8].

\subsection{Waterway "Roads" to Take Agricultural Products to Markets}

There are few roads throughout the Mekong River basin. Rural life revolves around rivers, canals and drainage ditches with many villages accessible only by rivers and canals. Agricultural products such as rice, cabbages, fruits and vegetables are transported on all kinds of boats from fields to cities and towns and distribution points along the canals (Figure 11). Once products arrive in an urban 


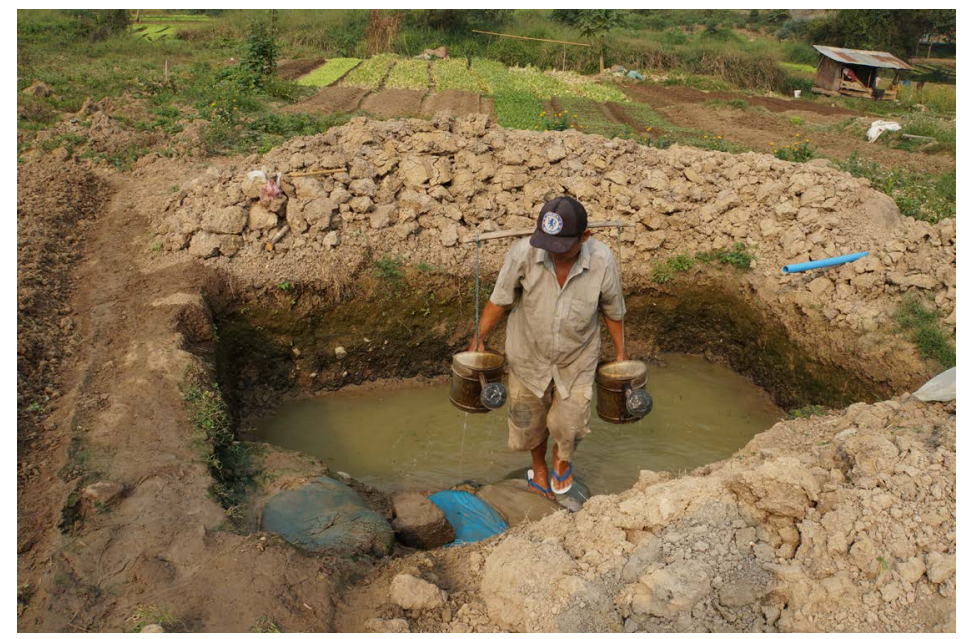

Figure 9. A Laotian vegetable farmer carries water to his crops during the dry season (March 2016).

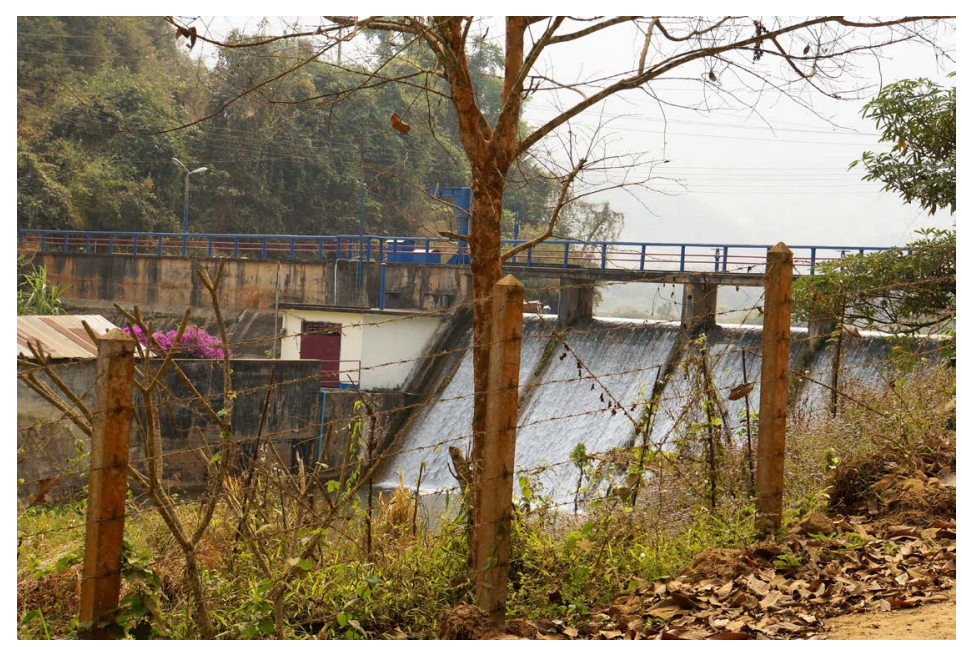

Figure 10. Small pocket dams on Mekong River tributaries provide electricity, reservoirs for fishing, and water to irrigate crops in the upland valleys of Lao PDR.

area they are loaded onto motorcycles for transport to local streets and store vendors.

Boats enable daily travel to fields and fishing places as well as are used to obtain seed, fertilizers and other off-farm products. They also transport rural families to visit friends, relatives, and their local wat where they meet for religious services, cultural events and educational training. Many farmers and fishers own a long-tailed motorboat that holds up to four passengers and transports a variety of goods to markets. The motorboat has an engine, driveshaft and propeller on a single detachable chassis mounted on the stern (Figure 5 ). The propeller chassis swivels in its mount so the boat can execute sharp turns through winding waterways at high speeds. The propeller can be raised out of the water while the engine is still running to prevent the blades from catching on clumps of floating water hyacinth which is ubiquitous in many waterways. The boat's propeller unit 


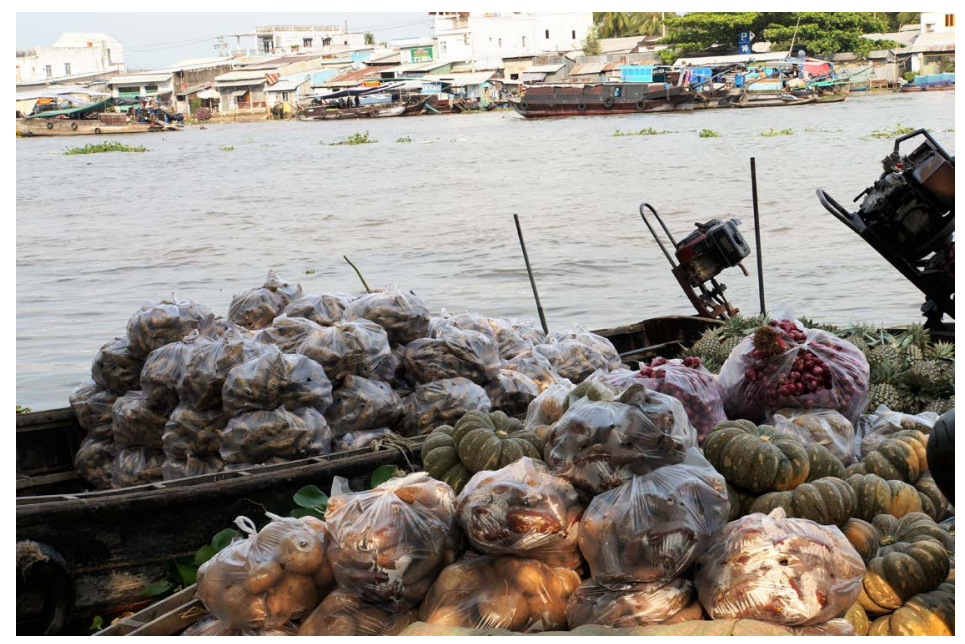

Figure 11. Pineapples, squash, onions, tubers and other fruits and vegetables are transported by boat from fields to cities and then transferred to motorcycles to distribute to local markets.

can also be used to pump water from flooded rice fields, thus draining them more quickly rather than waiting for the water to naturally drain. This allows the farmer to plant almost a month sooner-especially if growing a spring crop of the new short stemmed high-yield rice varieties. The boat has its own "garage" on the river or canal near the farmer's home-a hut made of water coconut leaves that prevent the hull from filling with rain water.

\subsection{Non-Agricultural Livelihood Activities}

Many rural livelihoods consist of a combination of agricultural and non-agricultural activities [4]. Remittances from urban areas are often part of rural livelihood diversification strategies [4] [12]. One or two rural household members will move to the city to work and send back to the rural household a portion of their pay. For example, in the Vietnam Delta along the Mekong River, factories for many years have made bricks from local soils and supplemented rural and urban incomes. The river provides transport for raw materials, to bring in labor to the factories and to ship the bricks regionally and around the world [24]. Large beehive shaped kilns churn out millions of burnt clay bricks each year (Figure 12). A number of furnaces burn rice husks that heat the kiln to 1000 degrees Celsius and give off a fragrant smoke that is high in carbon dioxide. Some kilns are loaded by conveyer belt and use fuels such as coal which also contribute carbon dioxide to the atmosphere.

\subsection{The Geography and Natural Resources of the Mekong River Basin}

The lower Mekong River Basin is an environmentally complex region with particular biophysical constraints and opportunities for human settlement and livelihoods. It is home to more than 200 different ethnic groups, many whose ancestors have lived in the region for centuries. The cultures and occupations of 


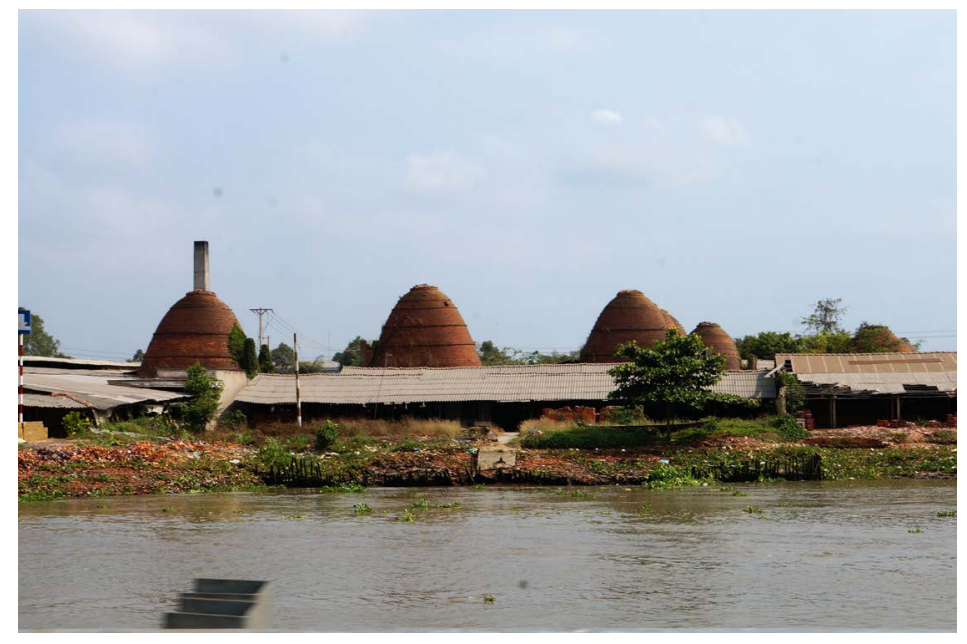

Figure 12. Bee hive shaped factories along the Mekong River produce millions of burnt clay bricks from local soils. The Vietnam government has begun to regulate the smoke and carbon dioxide in the air and is working to modernize this process for a safer work environment.

these ethnic groups (e.g. Khmer, Cham, Tai, Hmong, Jarai, Viet, Lao, etc.) are varied and diverse [7] and tied to the pulses and seasons of the Asian monsoon and the Mekong River. Their adaptation to geography and climate to make a living is co-mingled with rich histories, legacies of wars, and embrace of new technologies and modern innovations in efforts to create and recreate livelihoods.

The transboundary Mekong River, shared by China, Myanmar, Lao PDR, Thailand, Cambodia, and Vietnam originates in the mountains of Tibet and Yunnan Province, China, and drops from an elevation of $5000 \mathrm{~m}$ to sea level when it reaches the South China Sea (Figure 2). The reaches of the Mekong River reflect climate, historical tectonic events, and a great deal of local variations in slope, soil profiles, sedimentation and erosion patterns as well as anthropogenic activities. These variations influence the types of farming and fishing that occur along its path as it flows south $4350 \mathrm{~km}$.

The glaciated Himalaya Mountains confine the Mekong into steep, narrow gorges which widen slightly as the river enters northern Laos. Here the terrain alternates between mountain ridges and steep valleys with narrow floodplains and forested mountainsides. Large boulders and rocky rapids are highly visible during the dry season in the riverbed making river navigation dangerous for all but the most skilled. Plains are few and are primarily in river floodplains and where alluvial fans form at the confluence of major tributaries and the mainstem. Many kinds of vegetable crops and household gardens are grown in these alluvial soils as floodwater recede (Figure 13) [8].

As the bedrock-walled Mekong River flows south into alluvial lowlands near Vientiane, Lao PDR, the channel meanders with low radius bends. This alluvial channel at high flows can shift and change as banks are eroded, sediments are suspended and re-deposited in new places. The river at flood stage can take 


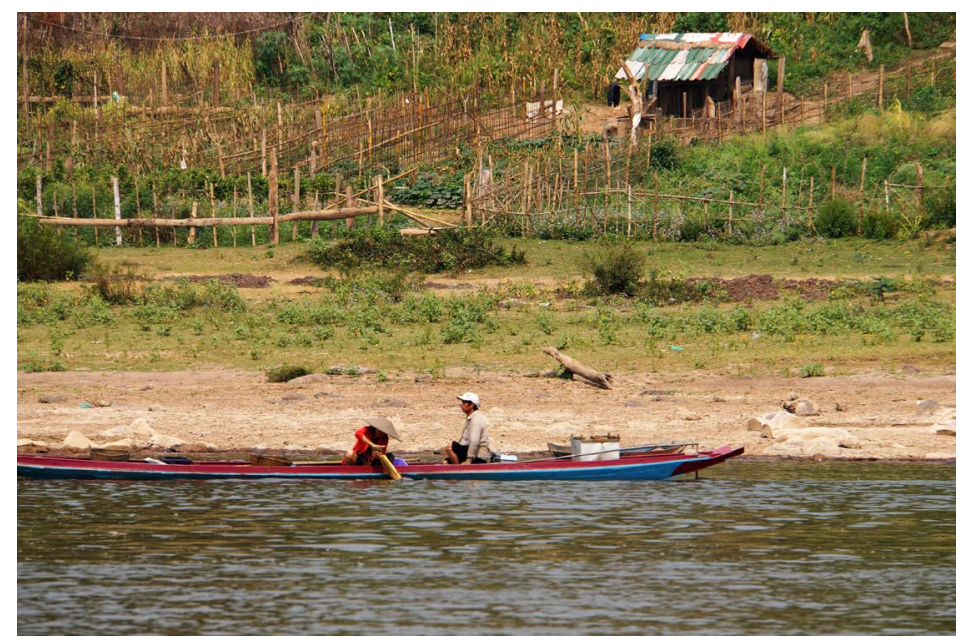

Figure 13. Farmers and fishers along the Mekong River and its tributaries use recession agriculture, a farming system of planting crops on fertile banks as flood waters recede to take advantage of soil moisture (March 2016).

short-cuts across the neck of a bend and create new islands and multiple channels as sediment deposits and water levels rise and fall with the season. Natural levees composed of silt and clay about 8 to $10 \mathrm{~m}$ high are along both sides of the river from Vientiane to the Mun River, Thailand confluence [25]. These fertile riverbanks, when they are not too steep are terraced and recession agriculture (Figure 13) uses the soil moisture from receding floodwaters with the onset of the dry season [8]. Wetlands beyond the levees are drained for rice paddies, corn (Zea mays L.), and vegetables.

The Mekong lowlands are bounded on the east by the north-south running Annamite Mountains range shared by Lao PDR and Vietnam and on the west by the Thailand Korat Uplands [26]. Volcanic activity during the Cretaceous period occurred throughout southern Laos, resulting in widespread eruptions of basalts. Basalt outcrops and fault lines near the Cambodia-Lao border underlie the spectacular Siphandone (4000 islands) and Khone Falls [25]. Here the river has alluvial deposits over the basalt and flows in numerous channels separated by large islands that are rather stable with mature vegetation $5-10 \mathrm{~m}$ above the low water mark. Fish are abundant is this area including the rare Irrawaddy dolphin (Orcaella brevirostris) and giant fish.

\subsection{A Tropical Climate}

The entire Mekong River Basin covers 795,000 $\mathrm{km}^{2}$ and annual discharge of fresh water on average is $457 \mathrm{~km}^{3}$. The river discharge and flood timing are very predictable and concentrated in a regular wet season peak [27]. The wet season, known as the summer monsoon, begins when warm moist winds from the Indian Ocean blow east over Thailand, Vietnam, Cambodia, and Laos bringing heavy rainfall. Flood season starts the end of June every year and lasts about 130 days. The beginning and ending of seasonal flooding has little variation, occurring 
within a two week period. The onset of the dry season is late November. The eastern tributaries of the Mekong River receive the highest amount of monsoon rainfall when heavy moisture-filled winds blow into the ridges and mountains of Laos and drop their loads. As a result Lao tributaries are a major source of monsoon flooding and discharge throughout the Mekong River Basin [27].

The annual wet season flooding of the Mekong (mid-May to early October) overtops natural river banks, spills into lowland rice fields, and submerges dry season river bank gardens after harvest. At the Mekong-Tonle Sap River confluence near Phnom Penh, Cambodia (Figure 1), flood waters annually back up into the Mekong tributary, the Tonle Sap River and reverse the river's dry season downstream flow [17]. As result, the Tonle Sap River flows into the Tonle Sap Lake enlarging its broad floodplain, bringing nutrient laden sediments, and an abundance of fish which the fishers of the lake eagerly await.

Downstream of Phnom Penh, the Mekong River divides into two main branches, the Bassac and Mekong and numerous tributaries (Figure 7) that during the wet season bring freshwater and replenish the fertile delta wetlands with upstream sediments. The lower Mekong Delta is a low-lying plain just barely above sea level. High levels of rainfall, prolonged flooding, incursions from seawater and strong tidal action make this a region with more water than land. Here the monsoon season freshwater is welcomed by farmers for rice cultivation and replenishment of drinking water supplies. During the dry season the coastal delta (Figure 7) lakes and canals become salty and the soil acidic [13].

\section{Modernization and Development Projects}

\subsection{Food Security: Agricultural Specialization and Intensification}

The Green Revolution-the spread of innovative agricultural research and technologies that brought high yielding rice varieties, synthetic fertilizers, pesticides, and irrigation to the world, transformed SE Asia in 1980s and 1990s. SE Asian growing populations, increasing urbanization and industrialization have led to improvements in communication, roads, bridges and other infrastructure that have enabled expanded agricultural markets and increased opportunities for farmers and fishers to rise above subsistence livelihoods [11]. Food production is a food security issue, a livelihood strategy, and a valued national export product. Over the last three decades Vietnam, Cambodia and Lao PDR have invested in agricultural specialization and intensification to increase food production and improve rural incomes.

Food security, a national concern for all SE Asia countries, is focused on ensuring food is available and their populations have access to sufficient, safe and nutritious food, clean water to prepare and insure sanitary conditions, and a food supply that is stable despite chronic and cyclical shocks [11] [28]. Vietnam, Cambodia and Lao PDR have strengthened their population food security since 1990. Cambodia's global hunger index dropped from extremely alarming at 31.7 in 1990 to 19.9 in 2011 and Lao PDR hunger index decreased from 29.2 (alarm- 
ing) in 1990 to 20.2 in 2011 . Vietnam has a stronger economy than both countries and made considerable progress in reducing their hunger index from 25.7 in 1990 to 11.2 in 2011. These indices compare to Thailand at 8.1 and China at 5.5 in 2011 [11], a reminder that Vietnam, Cambodia and Laos continue to have substantial food security challenges. Fullbrook [11] observes that improvements in food security do not necessarily imply households are less vulnerable to "acute deteriorations in food security." Disruptions to livelihoods can quickly make a household food insecure. Further Fullbrook [11] notes that the high cost of food relative to wages can lead to rapid swings in food security particularly when food costs range from $50 \%$ to $71 \%$ of household spending.

Rural households historically made their living from diverse assets: natural resources where they live (e.g. climate, land, water, fish, trees); their own skills and physical labor; and community and kinship relationships and networks. Wealth was based in these non-cash assets [4]. The inputs for traditional systems of rice production and wild fish catch are primarily generated from on-farm and proximate soil and water resources. Modernization of agriculture-aquaculture, farmed catfish and shrimp and machines to plant and harvest more hectares of high yielding rice has altered that system and depends on specialization, outside inputs and a cash economy. The resulting increase in agricultural production has enabled farmers and fishers to better meet demands of expanding markets for food.

Agricultural intensification has been a national goal for many SE Asian countries since the 1980s. Transforming traditional rice systems into modern production systems entails two rice cropping seasons per year (Figure 14) via increasing the hectares of paddy production and moving to irrigated dry season cropping

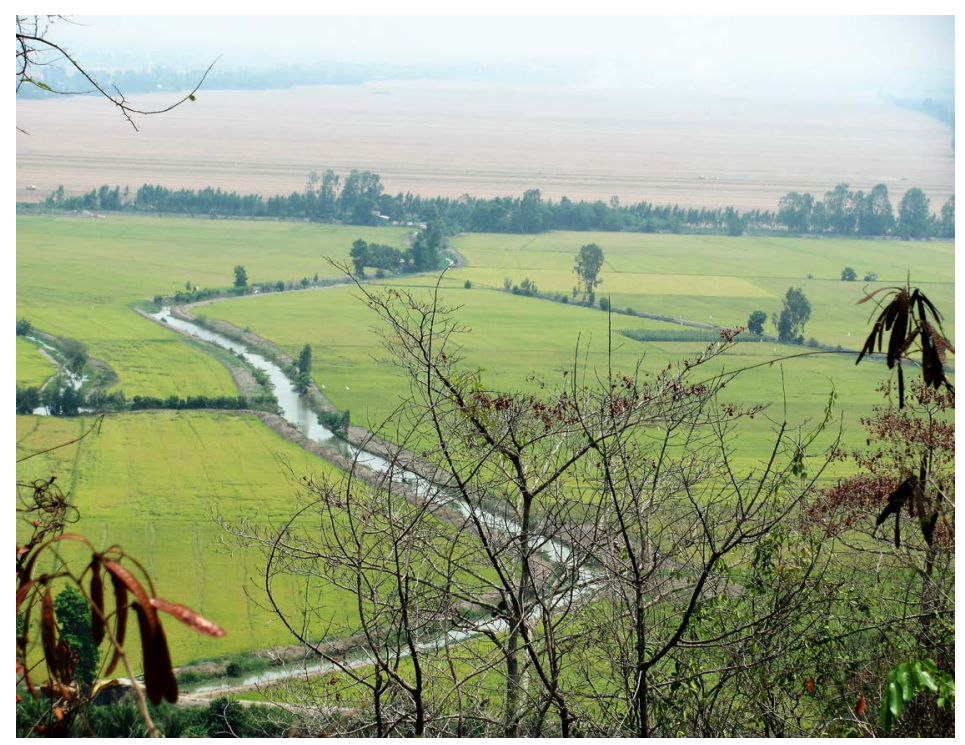

Figure 14. Dry season rice is grown as a $2^{\text {nd }}$ crop using a dike and polder system to manage water levels and irrigate during the growing season. In the background are brown rice fields lacking an irrigation or dike and polder systems. 
[3]. Vietnam, in 2010, produced $20 \%$ of the region's rice paddy crop, Cambodia $4 \%$, and Lao PRD 1\% [18]. More recently, Laos has set a goal of 5\% average annual growth in rice production through 2020 and increased cash crop production of maize, cassava, sugarcane, fruit, coffee, beans, roots and tubers and vegetable crops [3]. Achieving this transformation in rice production is built on managing and controlling the distribution of water year around in an attempt to reduce flooding and ensure a water supply in the dry season [20].

\subsection{Polders and Dikes}

Coastal dunes and natural levees adjacent to the Mekong River and tributaries were the original high points where farmers and fishers built homes, dug ponds to catch and hold rain water, planted fruit trees, and grew their gardens. An annual crop of wet season rice varieties tolerant to wet soils (and tolerant of acidic soils in the coastal delta region (Figure 7)) are grown on the lowland backwaters of these highpoints. The technology for transforming wet-swampy lowlands into productive two-to-three rice crops a year is based in the Dutch dike strategy of dikes and polders first initiated by the French in 1930s [29]. This system of controlling water levels in agricultural fields has several components (Figure 4; Figure 14): the polder or reclaimed drained lowland, dikes that surround the polders and prevent outside water from coming into the polder; a pumping station with pipes that bring water into the agricultural field (polder) from the canal or river during dry season and pump excess water out during the wet season. Internal ditches drain the polder and move excess water to the pumping station and distribute water when the soils of the polder become too dry and crops need additional moisture. Polders and dikes are connected to networks of canals and small rivers dredged to ensure water flow. The water network is linked to the Bassac and Mekong Rivers and their tributaries enabling multi-directional transport of seed, fertilizer, pesticides, and labor to fields and aquaculture ponds and shipping of grain and fish products to ports for regional markets and export.

Intensive drainage engineering combined with new short-stemmed, high yield rice varieties with shorter growing seasons enabled framers to switch to double cropping [13] and created an economic success story that has helped develop and modernize Vietnam [20]. Increased hectares planted to higher yield rice varieties require higher fertilizer inputs; pesticides; new machines for planting, weed control, and harvest; plus irrigation in the dry season. These new technologies depend on short-term and capital investments that are funded by farmers' surplus production and loans. Farmers that do not have surplus cash to purchase annual inputs and longer-term equipment accumulate debt in order to continue farming. Some have used their land as collateral and lost it when market prices drop and they could not repay their debt loads; and as a result have become agricultural labors rather than landowners [13] [20]. Despite these downsides, Taylor [13] reports that many of the Khmer ethnic groups in the Vietnam Delta region have prospered from the expanding market economy and their invest- 
ments in rice fields, shrimp ponds and cargo boats.

Dikes around fields with sluice gates, canal construction and dredging of tributary rivers in the Mekong delta were intended to increase the fresh water supply that rice need to grow and build the transportation to market network. Historically salt water incursions from the sea in the dry season meant that only one rice crop a year could be grown, when the monsoon rains brought fresh water to the rivers and flushed and diluted the saltwater [13]. In the Vietnam deltas hectares of irrigated rice are almost twice the hectares of rainfed paddies [18]. However, irrigation to produce a dry season rice crop has not been widely adopted by Cambodian and Lao farmers. Rainfed lowland rice production still dominates these farming systems. Both countries are investing in efforts to help farmers move from subsistence rice production to modern, market based systems. However, adoption of new technologies have had mixed uptake by smallholder farmers [3].

\subsection{Farmer Decisions to Adopt New Agricultural Technologies}

Research exploring Laotian rice farmers' decision-making and willingness to adopt new agricultural technologies reveals two distinct views that inform government strategies to modernize. Some farmers have embraced labor saving productivity and set maximization of yield goals; other farmers prefer to modify their traditional systems by selectively using only technologies compatible with their farming approach [3]. The first group of farmers seeks to maximize production using high yield seed varieties, purchase of synthetic fertilizers and the use of labor saving dry direct seeding machines to transplant rice. They are willing to use cash to purchase inputs to increase rice yields. Livestock production is their primary source of family income combined with other non-agricultural activities that contribute to the household livelihood (e.g. selling goods from a shop, furniture making, selling their labor and remittances).

In contrast, farmers who frame their management decisions from a traditional viewpoint focus on the importance of diversified on-farm activities as primary sources of income [3]. Use of high yielding rice seeds combined with livestock production (buffalo, cattle, pigs, chicken, and goats etc.) is their primary livelihood activities. They give high importance to vaccination of livestock to prevent disease and stock losses. Similar to the production-oriented farmers, traditional farmers use synthetic fertilizers but take a longer term systems approach to increasing soil fertility by using legumes. They also value extension agricultural advice on improving productivity using traditional methods. Traditional farmers did not seem particularly interested in labor saving-modern planting machines or engaging in the cash economy.

Neither type of farmer showed interest in water efficient production methods or irrigating for a dry season crop. These Laotian farmers are growing rice on lands with poor soils that are often waterlogged in the wet season and are not as fertile as the Mekong Delta region. They respond well to new seed and fertilizers 
that improve wet season productivity but are much more risk adverse to other technologies. Alexander et al. [3] conclude that rural households are adapting their individual livelihood strategies by diversifying their on-farm production, seeking off farm income, migrating to new locations with employment and sending remittances back to their households. Adaptation and adoption of new livelihood options and technologies seem to be considered relative to short-term costs, production yields, the cost of new technologies or options, profitability in the medium and long-term, and compatibility with their current systems [3].

\subsection{Hydropower}

Water diversion from the main stem and hydropower dam construction on the Mekong River and tributaries are occurring at a rapid pace, bringing electricity to rural places and irrigation to dry upland agriculture, promoting economic growth and providing important export revenues [8] [16] [30]. However, the pace of this modernization project is causing great upheaval and distress to farmers and fishers who have lived in river communities for generations and depend on the river ecosystem for livelihoods. Changes to livelihoods from dam construction take several forms: villages displaced by the dam reservoir and resettled elsewhere; farmers and fishers living downstream from dams experiencing river volume and flows considerably different than the predictable pulse of the monsoon wet and dry seasons; and changes in the river ecology and wetland habitats with cascading effects on fish and other aquatic species and their abundance [4] [9] [10] [15] [16] [31]. These social-economic-ecological changes are not well understood. The Mekong River Commission (MRC) has done a number of studies and AusAID CSIRO Research for Development Alliance and several universities are gathering, synthesizing and publishing archival and cross-sectional data as well as establishing longer-term studies to guide public policies to address livelihood effects [6] [9] [32].

Over $70 \%$ of the Mekong River stream flow comes from snow melt in the upper Mekong catchment (China) from May to July ( 16\%) and the summer monsoon rain (July to October) runoff from the Lao mountain tributaries (55\%) [30]. These mountain streams are a valued water resource Lao PDR is harnessing, with 17 tributary hydropower dams in operation and another 99 planned to provide electricity to stimulate economic growth [16]. More contentious are two main stem hydropower dams, Xayaburi and Don Sahong, Laos, a third one north of Luang Prabang (Pak Beng dam) under construction, and eight or more proposed by Lao PDR and Cambodia on the Mekong main stem (Figure 2) [8].

Several studies have begun to assess the social, economic and ecological impacts of the Laotian dams and their impacts on rural livelihoods [4] [9] [10] [16] [31]. An examination of altered river-based livelihoods upstream from a tributary dam before and after resettlement of four villages finds that post-resettlement villagers' access to domestic water supplies had increased, some households began specializing fisheries, and income sources became more 
concentrated and less diverse [31]. Riverbank gardens (Figure 13) that were sources of household food security and cash income were lost; and there was an overall $45 \%$ reduction in average plot size after resettlement. This led to reductions in crop production and drops in average household incomes.

The experiences of these villages reflect the fears other villages scheduled for resettlement have, with particular concerns about losing fisheries livelihoods, food security, and changes in social relationships when household members have to seek employment out-of-community to support the household [15]. A number of farmers and fishers in this region perceive they have historically been taken advantage of and express low trust in their government and neighboring countries. Most of all they fear losing their way-of-life because that is all they know, and resettlement threatens to fragment kinship and social relationships [15]. It is not clear whether this is a transitional economic situation and the extent to which resettled farmers and fishers will adjust livelihood strategies to rebuild household incomes and climb out of poverty. Joint efforts by the Laotian government and hydropower corporations have put in place dam mitigation interventions and are tracking environmental changes and sustainability of the new livelihood systems [10]. However, with reductions in loss of income options, limited training on new technologies and little infusion of capital for starting new occupations, the flexibility of rural people to spread risk or shift to other livelihood strategies is diminished.

\subsection{Realigning the Pulses of the Mekong and Farmer and Fishers Livelihoods}

Modernization projects are intended to bring industrial and economic growth and improved quality of life such as basic services like electricity and safe water, reduced poverty, and widespread food security. Underlying many development efforts are assumptions about traditional natural-human systems as inadequate to achieve these social goals. Assumed also by many SE Asia nations is that social progress means changes that inevitability alter the current pulses of both the Mekong River system and the livelihoods that utilize them. Two of these changes are large scale: hydropower infrastructure and agricultural specialization and intensification. The challenge is how to re-align progress goals with rural traditions and ensure the integrity and sustainability of river ecosystems to support multi-uses.

Energy is a central tenet of sustainable development and provision of services to rapid urbanization and population growth. Electricity is projected to make up $40 \%$ of all world energy consumption by 2040 with SE Asia accounting for two-thirds of future global energy demand largely due to an emerging urban middle class [33]. Agricultural intensification is also an energy user, depending on fuels for irrigation pumps and transport systems as well as production of fertilizers and other farm inputs from off-farm sources. The scale of need for reliable, affordable low carbon energy places hydropower from rivers high on the list of renewable, clean energy. Hydropower is the primary renewable energy source 
in Cambodia, Myanmar and Lao PDR (Figure 10). Fifty percent of Cambodia's power in 2015 came from hydropower and, overall, hydropower in 2016 contributed $14 \%$ of the region's power mix [33]. Access to clean electricity reduces household air pollution linked to premature deaths and millions of hours spent, mostly by women, collecting firewood, grasses, and fuels for cooking and heating [33]. Air pollution tolls on public heath are of great concern and energy intensive industries, such as steel, paper, aluminum, cement and aging brick kilns are facing requirements to move to clean air production systems. The International Energy Agency [33] notes that hydropower is a significant untapped resource available to meet local demand and export, but large scale projects on the Mekong River raise significant environmental, social, and rural livelihood issues that must be addressed.

Living adjacent to or on the Mekong River and its floodplains (Figure 15) would seem to be a high risk endeavor for farmers and fishers who are continually exposed to annual flooding, intraseasonal drought, freshwater displaced by saltwater in the dry season, rising sea levels and waterlogged and acidic soils that are not well suited to rice, fruits or vegetables. Many would say these are vulnerable people living in ecosystems that are not especially hospitable to community settlements and making a living. However, the farmers and fishers of the Mekong River Basin have developed unique relationships with their water and land resources and learned over many hundreds of years to adapt. Their cultural and economic practices are based on the river's dependable dry and wet season pulses and the aquatic species that have adapted to the river pulse and the unique habitats it spawns [17]. It is this deep relationship with their natural resource base that gives rural people capacities to be self-reliant, build communities, and identities that are water-soil based. The special knowledge they have

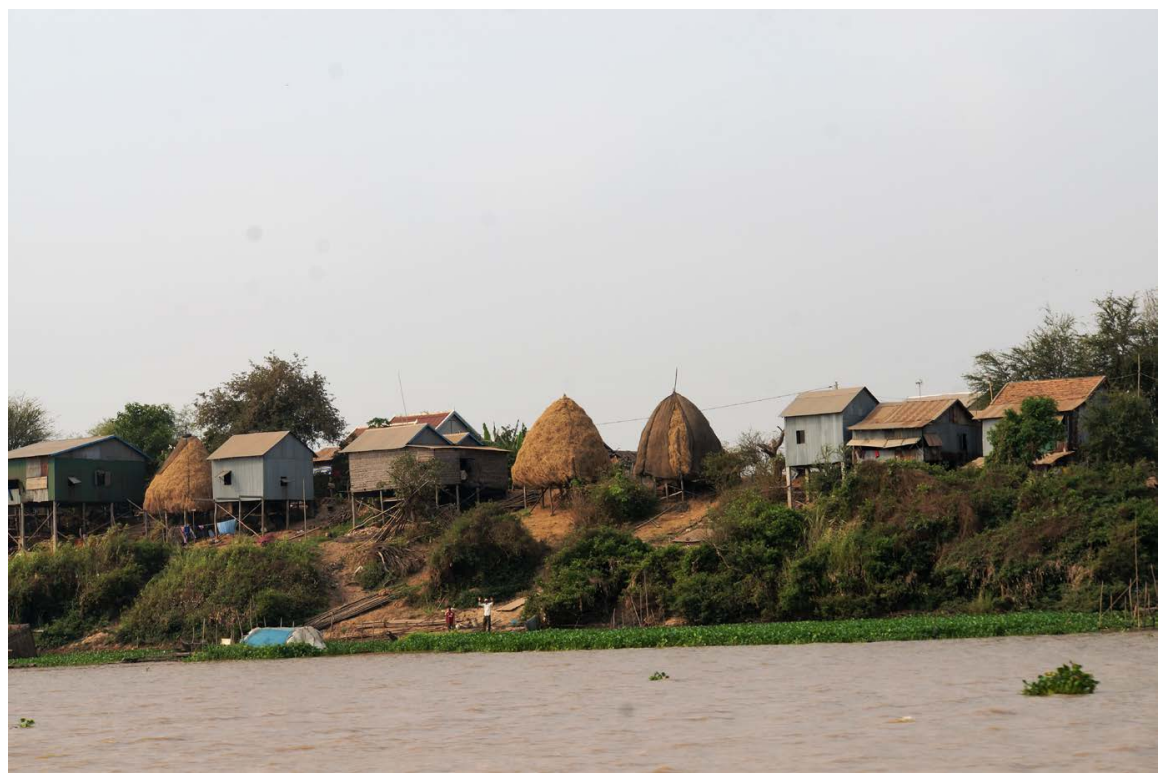

Figure 15. Farmers and fishers along the rivers in the Mekong basin build their homes and hay storage on stilts upon natural levees, the highest places in the river lowlands. 
gained from their own experience and the legacy of prior generations have enabled them to inhabit lands that many find uninhabitable and unsustainable. Their adaptations are influenced by many factors including learning processes that entail multiple feedback loops that integrate biophysical, social, and economic information and experiences to produce new understandings and guide decisions about when and how to adjust practices and livelihoods (or not) [3] [34]. This suggests they have capacities to continue to change if they have sufficient resources.

Agriculture has been a fundamental livelihood strategy for SE Asia farmers and fishers. It is basic to human well-being but has become a major source of environmental decline worldwide and in SE Asia. The need to increase production to achieve food security for all is only part of the sustainability equation [35]. Agricultural intensification has had unintended consequences. Canals along the coast bring in sea water for shrimp ponds, making the soil more acidic and the drinking water unsafe. The rainy season brings abundant fresh water via canals and river tributaries but local waters and the soils in the dry season become concentrated with salt and acidic making drinking water scarce [36]. Further, an increase in fertilizer and pesticide use has decreased fish stocks in the waterways [13]. Sufficient fresh drinking water is a constant concern in many parts of the Mekong Delta where saline and fresh water supplies intersect and dry season rivers and wells dry up. A challenge to intensifying rice production in southern and central rice region of Lao PDR is poor soils and lack of dry season water. Farmers have traditionally relied on rainfall to produce their rice crop [3] and often have neither financial resources nor knowledge-based skills to add a second irrigated crop.

Some agricultural intensification strategies developed to meet the needs of expanding populations and improved output to input ratios have caused managed ecosystems to cross critical thresholds-soil organic C (SOC) lost from lands not protected from wind and water erosion, freshwater resources degraded by too much $\mathrm{N}$ and sedimentation, and irrigation practices that modify hydrologic cycles and lead to soil salinization [37]. These realities inevitability turn to questions about agricultural intensification sustainability. How can farmers and national agricultural policies better respond to changing conditions to support and strengthen agroecosystem functions and services? What practices and policies are needed to create productive and profitable agricultural systems and concurrently promote the river environment and improve the quality of life for farmers and society it feeds?

A key to improving sustainability of the Mekong River Basin lies in enhancing the ability of human-natural systems to absorb shocks and changes while retaining valued functions, not in optimizing isolated components of the system [38]. A goal in readjusting and adapting livelihoods and the riverine ecosystem to disturbances and uncertainties associated with changing conditions is to avoid catastrophic loss of these systems [39]. Negotiating the tradeoffs in developing 
better human-natural integrated systems rather than focusing on component parts: energy or food production or livelihoods or environmental preservation is not easy but necessary.

The farmers and fishers of the Mekong River Basin are constantly managing their changing environment to produce livelihoods. The river pulse has historically been predictable with the onsets of wet and dry seasons anticipated from past experiences. Crops are planted along river banks as the flood waters recede and soils hold moisture for germination and plant growth with the onset of the dry season. Fishers prepare their boats and nets for the wet season turbulent floodwaters and big fish catches. Rice farmers wait for the wet season to plant and water their crops and the dry season to harvest. They know that their rivers are complex and dynamic and continually erode banks, transport nutrient-laden sediments and re-deposit them in their fields as the flood recedes. The velocity and volume of water the river and tributaries carry shift with the seasons, producing an abundance of water in the wet season and drought conditions in the dry season. Fish swim up the main stem and into tributaries to spawn, hatching fry that will swim back into the main stem with the monsoon rains. Although flooding can threaten their livelihoods, over centuries they have learned to adapt and to manage changing conditions, assess risk and complexity to survive [13].

However, adaptation has increasingly become more challenging as the pace of change has accelerated due to agricultural specialization and intensification, rising sea levels, hydropower dam construction, industrialization and modernization. These changes affect livelihood decisions and the mix of household activities undertaken to make a livelihood. Livelihood diversity has historically been a successful strategy for making living. Modern agriculture has replaced diversified farming with specialization and intensified farming systems. Dam construction is interrupting the predictable monsoon flooding and seasonal flows of the Mekong River and its tributaries. Rural capacities to adapt and rebound from these disturbances while continuing to retain occupational, social, and cultural structure and desired functions are presenting new challenges and resource needs.

\section{Conclusions}

The farmers and fishers of the Mekong River and its tributaries can bring their knowledge of the past forward to manage and adapt to changes in the pulses of the river and their livelihoods. But they need resources, training, and public policies that build on their knowledge and skills and remove barriers to successful adaption. And they need social, political and economic signals that reaffirm their value and contributions to the well-being of their communities and society. Development projects and the modernization of this region, as currently envisioned are threats to the food security and incomes of rural people, as well as their communities and ways-of-life. To mitigate the collision of modernization with the cultural traditions and practices of farming and fishing that have sustained 
more than $2 / 3$ of the population for centuries requires understanding of these occupations as sources of livelihoods and community. New technologies do not by themselves transform nations, rather it is the way people respond to technologies and use them to achieve individual and societal goals. This tension is reflected in the two distinct views Laotian farmers expressed-some whole-heartedly embracing new technologies and others more cautiously selecting technologies congruent with their traditional world views. The entire continuum of these approaches is viable and valuable in bringing change and meeting social goals of economic prosperity and improved quality of life.

Agricultural intensification, large dams, roads, bridges and other infrastructure have been proven technologically to expand agricultural yields and outputs, generate power and provide a return on investment. However the social and environmental results of modernization often leave many behind. The Mekong River and adjacent lands are where the poorest people in SE Asia live with average annual income less from US\$2000. They make their living from agriculture in the floodplains and fishing the banks of their rivers. Laos is a mountainous country and the fertile soils are in the narrow floodplains. Dams flood fertile lowlands, and resettling rural people in uplands means the soils are different, often less fertile and not well suited to rice and vegetable crops they are familiar with. They will need to learn new agricultural practices, different fishing strategies (river versus lake) and use different fishing equipments. This kind of change takes time and personal resources that people often don't have. River bank fishing and recession agriculture provide food, income, and cultural continuity. Resettlement in many instances means reduced food security and movement to a cash economy where they have to pay for electricity, water, and food not grown from a very limited household income.

The Mekong River presents a huge opportunity for hydropower that can modernize Lao PDR and Cambodia and provide a needed infusion of external dollars to build the infrastructure necessary to grow their economies. The United Nations sustainable development 2013 agenda to address poverty and hunger depends on rural transformations that increase the number of people living above the poverty line [1]. Critical in this effort is not just the economic number assigned the boundary between poverty and non-poverty but careful attention to economic and non-economic aspects of rural livelihoods that ensure household self-reliance. In the rush to modernize, profitable markets can lead to concentration of food production in large commercial farms, large processers and retailers; leaving smallholders behind. "To ensure that small-scale producers participate fully in meeting the food demand, policy measures are needed to reduce barriers limiting their access to inputs, foster adoption of environmental sustainable technologies and approaches, increase access to credit and markets, facility mechanization and agricultural extension outreach and strengthen land tenure rights" [1].

The tensions among different sectors and how river resources (water, flood- 
plain soils, wetlands and back waters and adjacent upland) are valued are not unique to the Mekong River and its tributaries but can be seen globally. The Mekong River Basin is experiencing many of the same social, economic and biophysical challenges associated with human settlement patterns, industrialization, climate change and political viewpoints. In the United States (US) the US Army Corps of Engineers (USACE) has authority and oversight to manage flooding and balance the various social values of large and smaller river resources: navigation, agriculture, industrial uses, drinking water, and river ecosystems [37]. The Mekong River Basin has similar challenges, but as a transboundary river has six countries with many more than six different goals and needs for the resource. The Mekong River Commission (MRC) is a fairly new governance structure, created to coordinate and assure the river is protected for future uses as well as current. However, it is only as powerful as the countries that fund it give respect and authority to its rules and regulations, even if they don't agree with them always. This is a difficult governance challenge which must be worked through if the Mekong River is to effectively and sustainably serve these many competing needs.

The challenge is to build on rural people's knowledge, rethink the scale of development to bring these valuable resources-human and biophysical forward into the future in ways that address rural needs and the region quality of life. Large-scale agricultural intensification and dam infrastructure and water diversion, unchecked will reduce small-scale land holdings and farmers and fishers capacities to provide daily food for their own consumption and surplus produce and fish for household incomes.

The effect of dams on the seasonal pulse of the Mekong, fish diversity and abundance and downriver impacts on water availability are just beginning to be understood and need significant and systematic research and investments on the interacting effects among river systems and livelihoods. Guerry et al. [40] call for the development of solid evidence linking decisions to impacts on natural resources and ecosystem services and human well-being. Closing the gap in fundamental interdisciplinary sciences of river ecosystems and social-human sciences will enable the development of knowledge, tools, and practices and will go a long way in helping farmers and fishers realign their livelihoods to provide economic and social well-being.

It will be critical that development and management efforts recognize, value, and invest in rural people's roles in producing a stable, affordable food system and managing the integrity of river ecosystems upon which future prosperity depends. Interventions are needed to prevent degradation of the Mekong Basin soil and water resources from large-scale agricultural intensification, water diversion and overbuilding and locating of hydropower dams which are threats to sediment and nutrient delivery, fresh water supplies, peak flows on the Mekong and Tonle Sap rivers, salt water intrusion in the Mekong Delta, fish spawning, land subsidence in the Mekong delta, small-scale land holdings and farmer and 
fishers capacities to provide daily food for their own rural family consumption and to feed SE Asia's and the world's growing urban and rural populations.

\section{Acknowledgements}

Published with funding support from the Director of the Illinois Office of Research, College of Agricultural, Consumer, and Environmental Science, University of Illinois, Urbana, Illinois and the Iowa Agriculture and Home Economics Experiment Station, College of Agriculture and Life Sciences at Iowa State University, Ames, Iowa.

\section{References}

[1] FAO (2017) The State of Food and Agriculture. Leveraging Food Systems for Inclusive Rural Transformation. Food and Agriculture Organization of the United Nations, Rome, Italy. http://www.fao.org/3/a-I7658e.pdf

[2] Hortle, K.G. (2009) Fishers of the Mekong River Basin. In: Campbell, I.C., Ed., The Mekong Biophysical Environment of an International River Basin, Elsevier, New York, 197-250.

[3] Alexander, K.S., Parry, L., Thammavong, P., Sacklokham, S., Pasouvang, S., Connell, J.G., Jovanovic, T., Moglia, M., Larson, S. and Case, P. (2018) Rice Farming Systems in Southern Lao PDR: Interpreting Farmers' Agricultural Production Decisions Using Q Methodology. Agricultural Systems, 160, 1-10. https://doi.org/10.1016/j.agsy.2017.10.018

[4] Martin, S.M. and Lorenzen, K. (2016) Livelihood Diversification in Rural Laos. World Development, 83, 231-243. https://doi.org/10.1016/j.worlddev.2016.01.018

[5] Bouapao, L. (2017) Livelihoods and Migration. In: Smajgl, A. and Ward, J., Eds., The Water-Food-Energy Nexus in the Mekong Region: Assessing Development Strategies Considering Cross-Sectoral and Transboundary Impacts, Springer Science+Business Media, New York, 143-178.

[6] Campbell. I.C. (2009) The Mekong Biophysical Environment of an International River Basin. Elsevier, New York.

[7] Goscha, C. (2016) Vietnam. A New History. Basic Books, New York.

[8] Olson, K.R. and Morton, L.M. (2018) Water Rights and Fights: Lao Dams on the Mekong River. Journal of Soil and Water Conservation, 73, 35A-41A. https://doi.org/10.2489/jswc.73.2.35A

[9] Smajgl, A. and Ward, J. (2017) The Water-Food-Energy Nexus in the Mekong Region: Assessing Development Strategies Considering Cross-Sectoral and Transboundary Impacts. Springer Science+Business Media, Springer, New York.

[10] Sparkes, S. (2014) Sustainable Hydropower Development: Theun-Hinboun Expansion Project Case Study, Laos. Water Resources and Development, 4, 54-66. https://doi.org/10.1016/j.wrr.2014.09.002

[11] Fullbrook, D. (2017) Food Security in the Wider Mekong Region. In: Smajgl, A. and Ward, J., Eds., The Water-Food-Energy Nexus in the Mekong Region: Assessing Development Strategies Considering Cross-Sectoral and Transboundary Impacts, Springer Science+Business Media, New York, 61-104.

[12] Ellis, F. (2000) The Determinants of Rural Livelihood Diversification in Developing Countries. Journal of Agricultural Economics, 51, 289-302.

[13] Taylor, P. (2014) The Khmer Lands of Vietnam: Environment, Cosmology, and So- 
vereignty. In: ASAA Southeast Asia Publication Series, University Hawaii Press, Honolulu.

[14] Vaddhanaphuti, C. and Gyorvary, S. (2015) Land and River Grabbing: The Mekong's Greatest Challenge. Chiang Mai University, Thailand, Center for ASEAN Studies. The Regional Center for Social Sciences and Sustainable Development, Faculty of Social Sciences. Chiang Mai University, Thailand.

[15] Sykham, D. (2015) Potential Impacts on Women's Livelihoods from the Don Sahong Dam in Khong District, Champasak Province, Lao PDR. In: Vaddhanaphuti, C. and Gyorvary, S., Eds., Land and River Grabbing. The Mekong's Greatest Challenge, Center for ASEAN Studies, Chiang Mai University, Thailand, 68-97.

[16] Katus, S.D., Suhardiman, S. and Sellamutu, S. (2016) When Local Power Meets Hydropower: Reconceptualizing Resettlement along the Nam Gnouang River in Laos. Geoforum, 72, 6-15. https://doi.org/10.1016/j.geoforum.2016.03.007

[17] Olson, K.R. and Morton, L.M. (2018) Tonle Sap Lake and River and Confluence with the Mekong River in Cambodia. Journal of Soil and Water Conservation, 73, $60 \mathrm{~A}-66 \mathrm{~A}$.

[18] Redfern, S.K., Azzu, N.J. and Binamira, S. (2012) Rice in Southeast Asia: Facing Risks and Vulnerabilities to Respond to Climate Change. Building Resilience for Adaptation to Climate Change in the Agriculture Sector, FAOIOECD Workshop Proceedings, 23-24 April 2012, 295-314. http://www.fao.org/docrep/017/i3084e/i3084e18.pdf

[19] USDA (United State Department of Agriculture) (11 June 2015) Southeast Asia: 2015/16 Rice Production Outlook at Record Levels. Commodity Intelligence Report, USDA Foreign Agricultural Service. https://ipad.fas.usda.gov/highlights/2015/06/Southeast_Asia/Index.htm

[20] Olson, K.R. and Morton, L.M. (2018) Polders, Dikes, Canal, Rice and Aquaculture in the Mekong Delta. Journal of Soil and Water Conservation, 73, 4.

[21] FAO (Food and Agriculture Organization) (2013) Edible Insects: Future Prospects for Food and Feed and Security. Six-Legged Livestock: Editable Insect Farming, Collecting and Marketing in Thailand. Khon Kaen University and FAO.

[22] Hallett. I. (2014) Breeding and Raising the House Cricket. Melissa Kaplan's Herb Care Collection. http://www.anapsid.org/crickets.html

[23] Annadya Staff (2013) Cricket Farming in Cambodia: A Sustainable Source of Supplementary Nutrition and Income.

[24] Fox D. (2016) Inside the Giant Beehive Kilns of the Mekong Delta. www.globejotting.com/vietnam-brick-factory/

[25] Carling, P.A. (2009) Geomorphology and Sedimentology of the Lower Mekong River. In: Campbell, I.C., Ed., The Mekong. Biophysical Environment of an International River Basin, Elsevier, New York, 77-111. https://doi.org/10.1016/B978-0-12-374026-7.00005-X

[26] Gupta, A. (2009) Geology and Landforms of the Mekong Basin. In: Campbell, I.C., Ed., The Mekong. Biophysical Environment of an International River Basin, Elsevier, New York, 29-51. https://doi.org/10.1016/B978-0-12-374026-7.00003-6

[27] Adamson, P.T., Rutherfurd, I.D., Pell, M.C. and Conlan, I.A. (2009) Hydrology of the Mekong River. In: Campbell, I.C., Ed., The Mekong. Biophysical Environment of an International River Basin, Elsevier, New York, 53-76. https://doi.org/10.1016/B978-0-12-374026-7.00004-8

[28] FAO (2006) Policy Brief Issue 2-Food Security. Food and Agriculture Organization of the United Nations, Rome, Italy. 
[29] Biggs, D. (2011) Fixing the Delta: History and the Politics of Hydraulic Infrastructure Development and Conservation in the Mekong Delta. In: Stewart, M.A. and Coclanis, P.A., Eds., Environmental Change and Agricultural Sustainability in the Mekong Delta. Advances in Global Change Research, Vol. 45, Springer-Science-Business Media, London, UK, 35-44. https://doi.org/10.1007/978-94-007-0934-8_3

[30] Pech, S. (2017) Water Sector Analysis. In: Smajgl, A. and Ward, J., Eds., The Water-Food-Energy Nexus in the Mekong Region: Assessing Development Strategies Considering Cross-Sectoral and Transboundary Impacts, Springer Science+Business Media, New York, 19-60.

[31] Kura, Y., Joffre, O., Laplante, F. and Sengvilaykham, B. (2014) Redistribution of Water Use and Benefits among Hydropower Affected Communities in Lao PDR. Water Resources and Rural Development, 4, 67-84. https://doi.org/10.1016/j.wrr.2014.09.001

[32] Stewart, M.A. and Coclanis, P.A., Eds. (2011) Environmental Change and Agricultural Sustainability in the Mekong Delta. Springer, New York. https://doi.org/10.1007/978-94-007-0934-8

[33] IEA (International Energy Agency) (2017) World Energy Outlook Special Report: Southeast Asia Energy Outlook. OECD/IEA.

http://www.iea.org/publications/freepublications/publication/WEO2017SpecialRep ort_SoutheastAsiaEnergyOutlook.pdf

[34] Morton, L.W., McGuire, J.M. and Cast, A.D. (2017) A Good Farmer Pays Attention to the Weather. Climate Risk Management, 15, 18-31. https://doi.org/10.1016/j.crm.2016.09.002

[35] Garnett, T., Appleby, M.C., Balmford, A., Bateman, I.J., Benton, T.G., Bloomer, P., Burlingame, B., Dawkins, M., Dolan, L., Fraser, D., Herrero, M., Hoffmann, I., Smith, P., Thornton, P.K., Toulmin, C., Vermeulen, S.J. and Godfray, H.C.J. (2013) Sustainable Intensification in Agriculture: Premises and Policies. Science, 341, 33-34. https://doi.org/10.1126/science.1234485

[36] Lan, N.T.P. (2011) From Rice to Shrimp: Ecological Change and Human Adaptation in the Mekong Delta of Vietnam. In: Stewart, M.A. and Coclanis, P.A., Eds., Environmental Change and Agricultural Sustainability in the Mekong Delta. Advances in Global Change Research 45, Springer-Science-Business Media, London, UK, 271-285. https://doi.org/10.1007/978-94-007-0934-8_16

[37] Olson K.R. and Morton, L.M. (2016) Managing the Mississippi and Ohio River Landscapes. Book Division, Soil and Water Conservation Society, Ankeny, IA.

[38] Walker, B. and Salt, D. (2006) Resilience Thinking: Sustaining Ecosystems and People in a Changing World. Island Press, Washington D.C.

[39] Park, J., Seager, T.P., Rao, P.S.C., Convertino, M. and Linkov, I. (2013) Integrating Risk and Resilience Approaches to Catastrophe Management in Engineering Systems. Risk Analysis, 33, 356-367. https://doi.org/10.1111/j.1539-6924.2012.01885.x

[40] Guerry, A.D., Polasky, D., Lubchenco, J., Chaplin-Kramer, R., Daily, G.C., Griffin, R., Ruckelshaus, M., Bateman, I.J., Duraiappah, A., Elmqvist, T., Feldman, M.W., Folke, C., Hoekstra, J., Karevia, P.M., Keeler, B.L., Li, S., McKenzie, E., Ouyang, Z., Reyers, B., Ricketts, R.H., Rockstrom, J., Tallis, H. and Vira, B. (2015) Natural Capital and Ecosystem Services Informing Decisions: From Promise to Practice. Proceedings of the National Academy of Sciences of the United States of America, 112, 7348-7355. https://doi.org/10.1073/pnas.1503751112 